\title{
An Overview: Recent Research and Market Trends of Indian Wine Industry
}

\begin{abstract}
Keywords: Research; Vitic ulture; Wine market; India
Abstract

The wine industry related to flavor science is one of the most globalized industries in the world. Even though wine was mentioned as Somras or Madira in Indian mythology it has been viewed as a European product. Despite several socio economic constraints, the Indian wine market has already tasted its share of recognition in the global market over the past few years. The increasing annual growth at $25-30 \%$ and the lower per capita wine consumption indicate immense potentiality of the untapped Indian wine market. The wine market depends on the wine production, consumption, imports and exports. This paper presents an overview of the research contributions and market trends of Indian wine industry. The contributions in the field of viticulture have been utilized by the industry and have led to the progressive economic growth of India.
\end{abstract}

\section{Research and Development in Grape Varieties, Microbial Strains and Fermentation Technology}

Day to day global competition within the wine market, consumer demands for refreshing wine flavors, a flow of advances in yeast biology, increasing concerns about the environmental consequences of wine production are posing new challenges for innovation in wine fermentation technology $[1,2]$. These will not only enable further refinements of existing technologies and products but also the development of new products based on the exploitation of new strains of Saccharomyces and non-Saccharomyces yeasts, novel bioreactor technologies and cultivation of fruits other than grapes.

Grapes are the prime source of wine production. India has 123,000 acres of vineyards, of which only $1 \%$ is used for wine production. The diversity of Indian soil and climatic conditions makes suitable for growing grapes in three distinct agro-climatic zones. The hot tropical zone suits export quality grapes more than the mild tropical, temperate and sub tropical zones. Grape production predominantly comes from Nasik, Satara, Sangli, Ahmed Nagar, Pune and Osmanabad of Maharashtra and the Nandi hills near Bangalore of Karnataka. Maharashtra is leading in cultivation, production and export of grapes. Screening of grape varieties is essential to check the suitability of red and white wine grape cultivation as these vary with the region. Shiraz, Cabernet Sauvignon, Pinot Noir, Zinfandel, Merlot, Cabernet Franc, Cinsault and Pinotage are the main red wine grape varieties; Sauvignon Blanc, Chenin Blanc, Ugni Blanc, Chardonnay, Clairette and Riesling are the major white wine varieties. The wine quality depends on the stage of grape maturation and is specific for each variety.

Fermentation of grape juice dominated by yeast strains, results in wine and is the nature's secret behind wine. Indian wine can be categorized into four different groups-red wine, white wine, sparkling wine and fortified wine. Grapes harbor lactic acid bacteria, acetic acid bacteria and other bacterial groups along with Saccharomyces

\section{Journal of \\ Food Processing \& Beverages}

\author{
Sarovar Bheemathati* \\ Department of Virology, S.V. University, Tirupati-517 502, Andhra \\ Pradesh, India \\ *Address for Correspondence \\ Sarovar Bheemathati, Department of Virology, S V University, \\ Tirupati-517 502, Andhra Pradesh, India, Tel: (+91) 8801747541; E-mail: \\ sarovarbhee@yahoo.co.in \\ Submission: 24 August 2015 \\ Accepted: 24 September 2015 \\ Published: 01 October 2015 \\ Copyright: (c) 2015 Bheemathati S. This is an open access article \\ distributed under the Creative Commons Attribution License, which \\ permits unrestricted use, distribution, and reproduction in any medium, \\ provided the original work is properly cited. \\ Reviewed and approved by: Dr. Andrew Reynolds, Professor of \\ Viticulture, Brock University, Canada
}

cerevisiae, involved in desirable fermentation are generally less in number [3]. During wine fermentation selection of yeast strains is based partially on production of total esters and aldehydes, and rate of sugar utilization [4]. Saccharomyces cerevisiae- strains no 10, 127,383 were superior in the production of wine. Occurrence of natural flora belonging to genera Endomycopsis spp., Hansenula spp., Kloeckera spp., Pichia spp., Rhodotorula spp., Torulopsis spp., and species Candida pulcherrima, C. guilliermondi, Debaryomycesvini, $K$. apiculata, S. chevalieri and Saccharomyces oviformis were recorded on different grape varieties from distinct geographical regions known for their production of special flavors during the initial stages of fermentation [5]. During the later stages, the accumulation of end products is toxic to these yeasts and they die off, leaving Saccharomyces cerevisiae to complete the fermentation. Fermentation conditions are allowed to ensure the growth of Saccharomyces spp. C. guilliermondi from Bangalore Blue wines; Candida spp., Kloeckera spp., Rhodotorula spp., Schizosaccharomyces spp., and Saccharomyces spp. from fermenting musts and wines of Beauty Seedless and Perlette grapes in Haryana have been isolated [6].

Despite a large vineyard area, cultivation of grapes is not encouraged because of heavy investments in establishing and managing the vineyards and high risk of losing the crop to adverse climatic conditions. Even though the cost of production is high, grape wine is known for its rich flavor and quality. Indian farmers are experimenting to adopt wine-specific varieties for better monetary gains than the normal varieties. Farmers should be encouraged to cultivate alternative sources such as peach, mango, apple, pear, plum, apricot, litchi, strawberry, cashew-apple, pineapple, pomegranate, banana, ber, kinnow, jamun, sand pear etc., [5] (Figure 1) as there is good demand for Indian fruit wines abroad and also would be helpful in decreasing the cost of production so as to meet the supply and demand ratio in the Indian wine market.

Diseases pose major constraints in the production of grapes and can lead to significant reduction in yield and berry composition which thereby affect wine quality. Grapes are attacked mainly by the diseases like anthracnose, downy mildew and powdery mildew and 


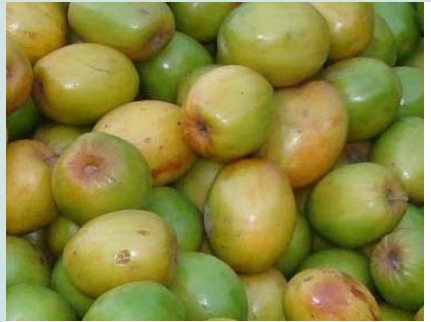

A) Ber

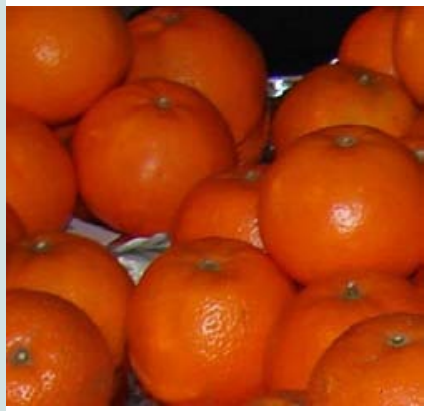

D) Kinnow

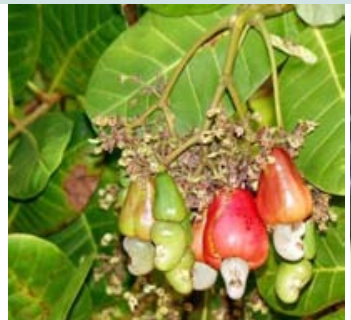

B) Cashew apple

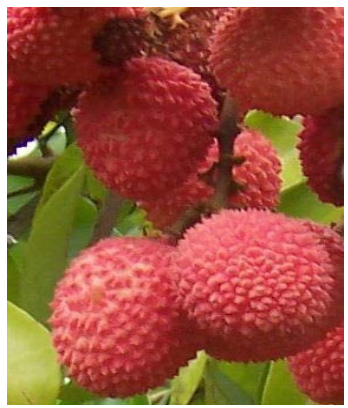

E) Litchi

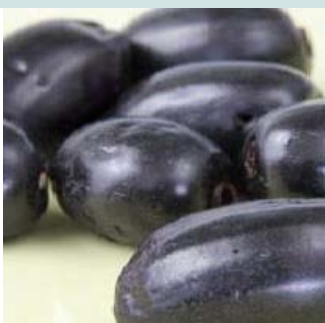

C) Jamun

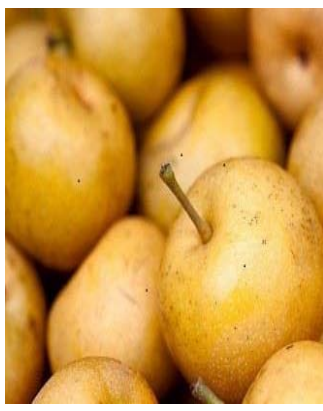

F) Sand apple

Figure 1: Common fruits used for wine production in India.

infested by pests such as flea beetle, mealy bugs, thrips, red spider mites, leaf hoppers, jassids and stem borers. Research institutes should help farmers in utilizing the disease forecasting models, integrated pest management programs and technology assistance in a suitable manner. Focus on transgenic would be helpful in developing pathogen-mediated transgenic resistance grapes.

Since the beginning of the current renaissance in wine industry, the research and development gave a new outlook to India's wine industry related to soil and agro-climatic conditions, selection of grape wine varieties, compatible root-stocks, importing diseaseresistant grafted vines, training, pruning, thinning, fertigation, irrigation, crop protection, choosing an appropriate method during fruit harvesting, contemporary vineyard practices, ranging from top-class soil and canopy management to a wide range of trellising methods, used to combat climatic extremes.

\section{Indian Wine Market}

\section{Wine production}

In India the three major wine producing regions are Maharashtra, Karnataka and Himachal Pradesh (Figure 2). Of these, Maharashtra is the largest producer and consumer of wine. After a decade of steady growth from 2000 to 2010, India's wine production dropped from 13.0 million liters (ML) in 2010 to $11.0 \mathrm{ML}$ in 2011 and improved slightly in 2012 to $11.5 \mathrm{ML}$ (1.3 million cases) [7,8]. FAS Mumbai forecasted the availability of Indian wine production at a record 17.3 ML in 2014 and excluding fortified wine, the production was recorded as 14.2 ML (Figure 3). The wine production estimates of Maharashtra and Karnataka is 14.2 ML (1.58 million cases) in 2014, as cooler temperatures during February and March improved grape yields and quality. The expanded production of key wineries has steadily raised the production of Karnataka and was estimated at $5 \mathrm{ML}(555,000$ cases), a jump of $1.3 \mathrm{ML}$ (145,000 cases) from the previously [9].
The decrease in wine production was mainly due to growers switching to table grapes and other crops, change in consumers drinking habit, drop in tourism, high land cost and state level land ceiling, wine policies and rupee devaluation. Even with all these obstacles the governments of Maharashtra and Karnataka have supported domestic wine industries by relaxing excise duties on local wines, easing distribution restrictions and providing fiscal incentives to establish wineries and vineyards, imposing excise taxes on imported and wines from other states. Especially Maharashtra

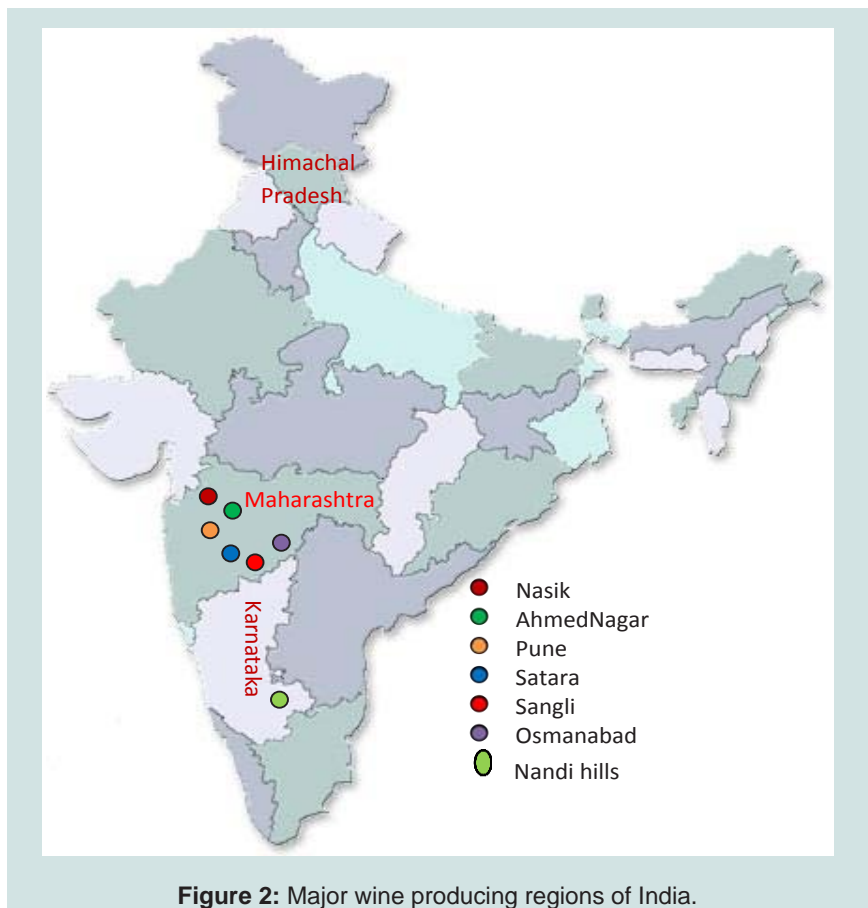

Figure 2: Major wine producing regions of India. 


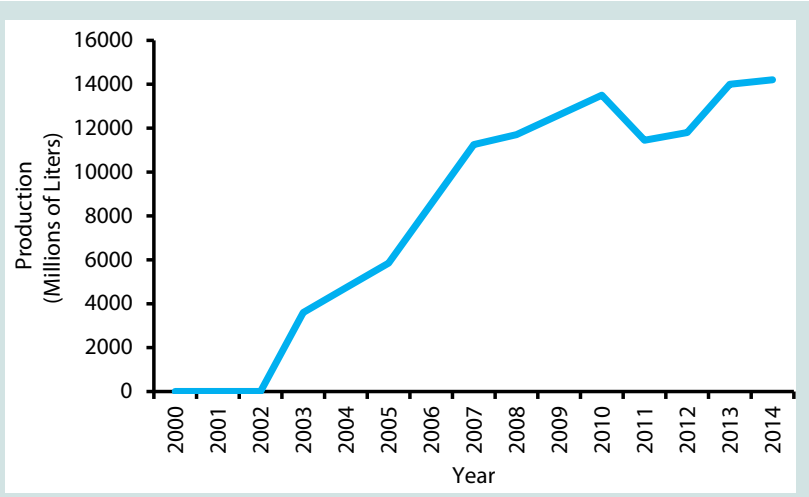

Figure 3: Wine production in India (2000-2014) [1,6-8]

has eased the license requirements and regulations for establishing wineries and wine retail outlets and established two wine industrial parks to facilitate investment in the industry [10].

\section{Wine consumption}

India ranks 77 th in terms of world wine consumption. The per capita consumption in India is only $0.07 \mathrm{~L} /$ person/year. The country accounts for $0.8 \%$ of the total wine consumed in Asia. In India $80 \%$ of wine consumption is confined to major cities such as Mumbai (39\%), Delhi (23\%), Bangalore (9\%) and Goa (9\%) [11]. Major factors adding to the higher wine consumption are growing population, higher disposable incomes, relaxation on government regulation and policies. Red wine is the most popular type of wine consumed in India followed by white and Rose wines. The consumption pattern of wine varieties is as follows: red wine accounting for $45 \%$ of consumption followed by white wine at $40 \%$, sparkling wine at $10-15 \%$ and rosé at $1-5 \%$. There was an increase of $16.3 \%$ wine consumption between 2012 and 2013. More than $61 \%$ of wine consumption is of red category and is expected to grow by $71.6 \%$ between 2013 and 2017 . In 2013 it was reported that 0.93 million cases of Indian wines were consumed as against to 0.28 million cases of imported wines [12]. Wine consumption appeared to be nil from 2000-2002 and improved slightly in a progressive manner from 2003, dropped in 2009 and slightly improved in 2010 and then the consumption levels reached gradually to $15 \mathrm{ML}$ in 2014 (Figure 4) [7-9,13].

According to the reports of All India wine associations, Indian wine consumption is expected to rise at a CAGR of around $18 \%$ during 2014-2015. The forecast of Vinexpo survey reveals that consumption of wine in India is expected to reach 2.1 million cases by 2017 , an increase of $73 \%$ from 2013. Indians will consume 1.15 million cases of red wine, 0.63 million cases of white wine and 0.10 million cases of Rose wine by 2017 [14]. According to the IWSR, wine consumption in India is expected to grow gradually and could reach 2.4 million cases by 2020 [15].

Wine tourism, will play a pivotal role in changing the market trends of Indian wine industry in near future. In India, wine tourism has emerged as the latest trend as is gaining significant momentum in creating economic opportunities in rural communities and the government should provide favorable government policies to make wine tourism a populous one.

\section{Wine exports}

Cabernet Sauvignon, Sauvignon Blanc and Chenin Blanc are the export quality wines to raise the stature of Indian wine in the global market. China, Singapore, Japan, Nepal and Bhutan are the potential markets for Indian wines and is gaining greater acceptance in US and France also. Presently, Indian wines are largely being imported by Malaysia, UAE, Bhutan, Germany, UK, Sri Lanka, Maldives and New Zealand. There was a modest rebound of $2.6 \mathrm{ML}$ in Indian wine exports during 2010 and had reached 739,000 L (2,100 cases) in 2012. The country's wine export was accounted for about ₹ 80 to 100 crores and is expected to increase by र 500 crores in the next five years [16]. India has the potential to become one of the major exporters of wine not only in Asia but also the world because of innovativeness in wine quality and marketing. According to the data of Ministry of Commerce, wine exports in 2013 were approximately $1.8 \mathrm{ML}$ valued at nearly US $\$ 7$ million. In the first seven months of 2014 , exports have increased by $20 \%$ especially for sweeter wines to Bhutan and Vietnam and export sales have grown by almost $40 \%$ by value compared to 2013 and have reached nearly US \$ 4.4 million [9] (Figures 5a and 5b).

\section{Wine imports}

Current Indian reported trade data suggests that the top three wine suppliers to India are France, Australia, and Italy and wine imports from "New World" wine countries is growing especially for Australian, American, South African and New Zealand products while imports from France and Italy have fallen [7]. After the setbacks of 2001 and 2008 due to the ban on imported wines and Mumbai terror attacks, there was a huge drop in Indian wine imports. Sales of imported wine are through hospitality (63\%) and retail (30\%) sectors, the two major marketing segments [17]. There was an increase in wine imports since 2009 and reaching a high of 44,000 hL in 2011 and are on pace to match that level in 2012 [7]. The Indian Ministry of Commerce reports the wine imports in 2013 equaled nearly $4 \mathrm{ML}$ and totaled almost US \$25 million. In the first seven months of 2014, imports were just over 1.7 ML and have totaled just over US \$10 million. In comparison with the first seven months of 2013, import volumes and values were down by over $27 \%$ and $28 \%$ respectively [9] (Figures 6a-6c). Lower domestic production and persistent promotion efforts appear to be yielding results for imported wines.

\section{Conclusions}

The budding Indian wine market has witnessed promising growth in the last five years. But, there are still lot more exciting challenges

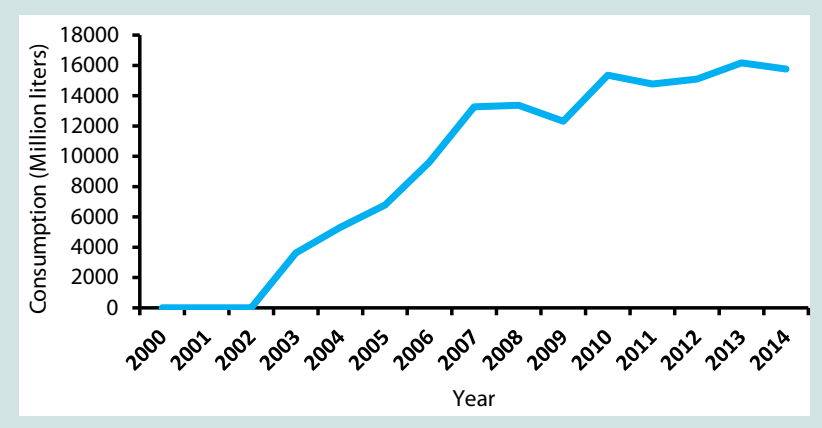

Figure 4: : Wine consumption in India (2000-2014) [1,6-8]. 


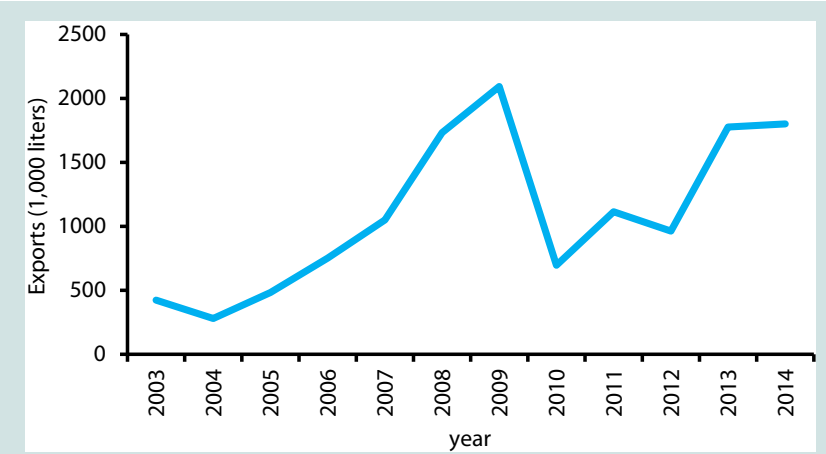

Figure 5a: Wine exports from India (2003-2014) [6-8].

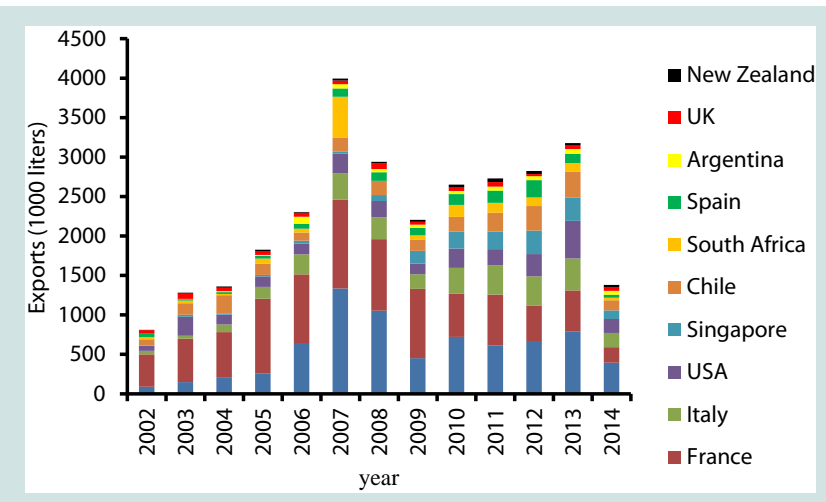

Figure 5b: Wine exports from India (2002-2014).

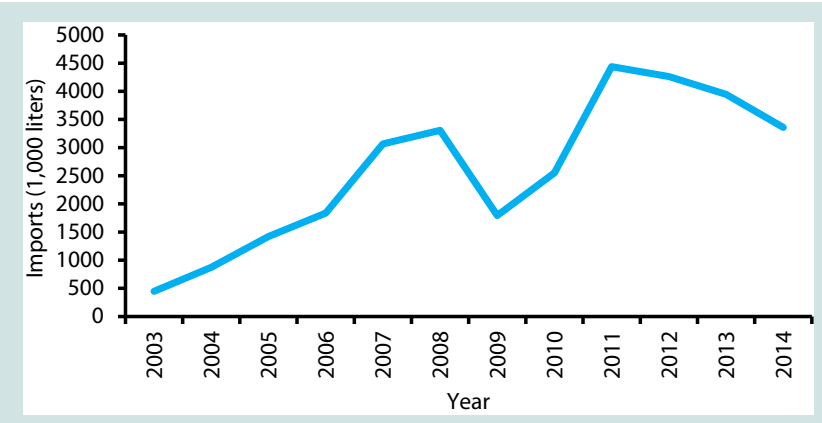

Figure 6a: Wine imports by India (2003-2014) [6-8].

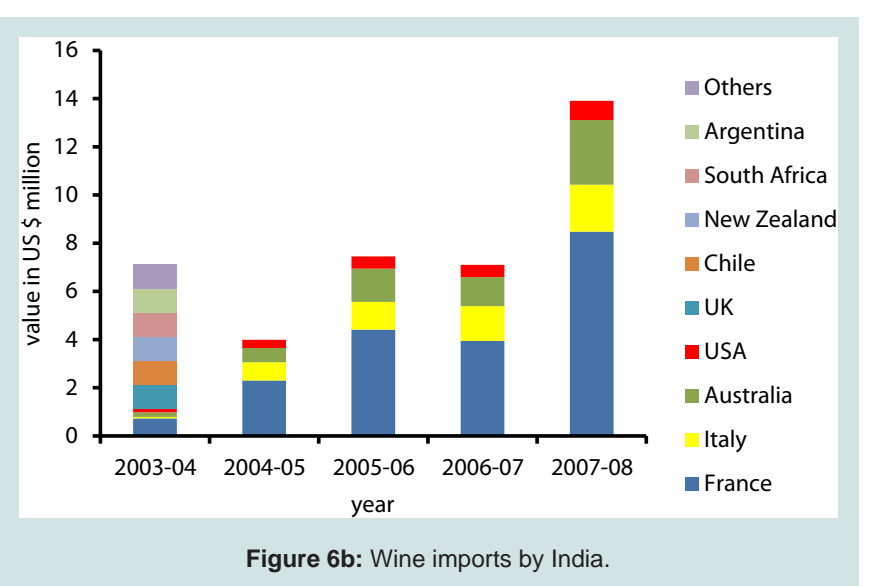

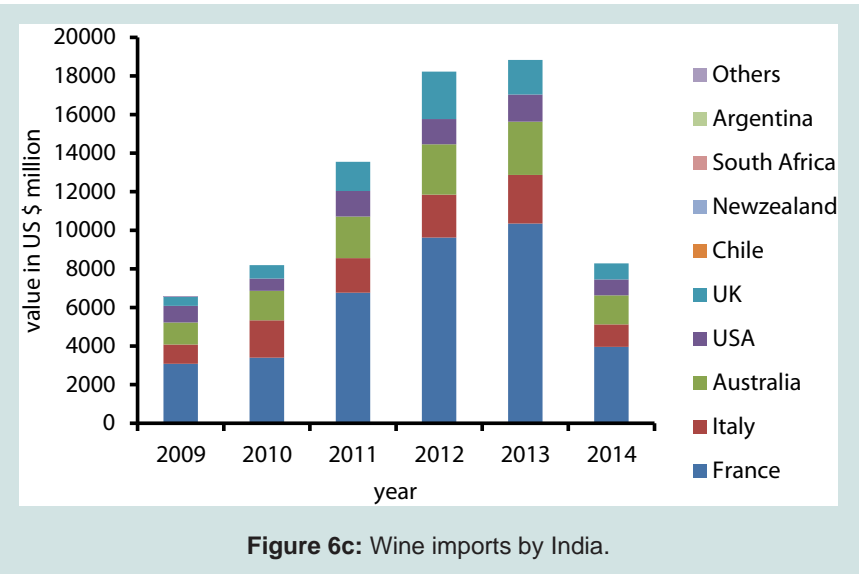

to face ahead. The Indian market and research institutes should concentrate on storage, transport facilities, wine exports, promotion through media campaigns and wine festivals, environmental issues regarding agrichemical usage, genetic resources and improvement, production technology, plant health management, pre and postharvest technology, cascading effect due to climatic changes on grape cultivation, grape juice composition, yeast ecology of wine production, fermentation kinetics and wine character. The Indian government has identified wine as a booming and blooming sector and has extended support in terms of subsidizing processing facilities and reducing VAT. The government should support research and development and encourage educational institutes to practice wine biotechnology for the genetic improvement of grape wines, wine yeasts and wine bacteria.

Indian wine has travelled a long adventurous way through time from Persia, Europe, Mughals, Portugal and Britain to India. The fledgling Indian wine market is ready to claim its deserving place in the colorful global wine market.

\section{References}

1. Bisson LF, Waterhouse AL, Ebeler SE, Walker MA, Lapsley JT (2002) The present and future of the international wine industry. Nature 418: 696-699.

2. Pretorius IS, Hoj PB (2005) Grape and wine biotechnology: Challenges, opportunities and potential benefits. Aust J Grape Wine Res 11: 83-108.

3. Mills DA, Phister T, Neeley E, Johannsen E (2008) Wine fermentation. In: Cocolin L, Ercolini D (eds). Molecular techniques in the microbial ecology of fermented foods. (C) Springer, pp. 162-192.

4. Venkataraman K, Patel JD, Subbarao MS (1979) Fermentation of grapes with a few strains of wine yeasts. Indian Food Packer 33: 13-14.

5. Joshi VK, Devender A (2005) Panorama of research and development of wines in India. J Scientific Ind Res 64: 9-18.

6. Trivedi LS, Ethiraj S (1979) Yeast flora from must, fermenting must and wines with and without spices. J Food Sci Technol 16: 143-146.

7. Sood D (2012) Wine market update 2012. USDA Foreign Agricultural Service, GAIN Report Number IN2162, Global Agricultural Information Network: 1-23.

8. Anderson K, Nelgen S (2011) Global wine markets, 1961 to 2009: a statistical compendium. Adelaide: University of Adelaide Press.

9. Dhruv S, Adam B (2014) Wine production and trade update. USDA Foreign Agricultural Service, GAIN Report Number IN4095, Global Agricultural Information Network.

10. Sathish BS, Chandra S (2012) Wine marketing an untamed market in India. Radix Int J Res Soc Sci 1: 1-17. 
11. Thaliath A, Kumar DN (2014) Impact of quality factors and internal factors in the buying decisions of wine patrons: Critical factors in bench marking wine tourism development and management. Int J Recent Scientific Res 5: 10911097.

12. Bhaduri S (2014) Wine consumption in India to increase $73.5 \%$ in four year.

13. Williams D, Mishra S (2011) The Indian wine market. USDA Foreign Agricultural Service, GAIN Report Number IN 1134, Global Agricultural Information Network

14. Vinexpo Asia-Pacific (2014) Hong Kong: The wine and spirits market in AsiaPacific and worldwide with prospects until 2017. From the VINEXPO* market study.
15. Sheth H, Pereira KA, Thomas TS, Kumar VK, Kelapanda MC, et al. (2014) Wine festival and wine consumerism-A perspective study on influence and awareness in the growth and acceptance of wine in Indian market. Int J Eng Technol Manag Appl Sci 2: 20-36.

16. APEDA (2012) APEX update showcasing Indian agri exports. Agricultural and Processed Food Products Export Development Authority (APEDA). Ministry of Commerce \& Industry, Govt. of India 18.

17. (2012) Indian wine industry report prepared by Western Australian Trade Office-India, Department of Agriculture and Food-WA Mumbai: 1-22. 